Interdisciplinary Studies of Complex Systems

No. 14 (2019) 61-80

(C) M. Bulatevych

https://doi.org/10.31392/iscs.2019.14.061

\title{
CONCEPT, PECUliarities OF CONSTITUTION AND FUNCTIONS OF CIVIL SOCIETY AS A STRUCTURAL ELEMENT OF THE MODERN WORLD-SYSTEM
}

\author{
Mykola Bulatevych ${ }^{1}$
}

\begin{abstract}
The article proposes to look at civil society from the standpoint of Immanuel Wallerstein's world-systems analysis. Of course, Wallerstein can hardly be considered a theoretician of civil society. Still, his works can offer theoretical provisions that concern this topic as well. The article suggests the study of civil society as possibly the third structural element of the modern world-system, which, along with two other structural elements - the axial division of labor and the state and the system of interstate relations, - regulates social relations in it. It is shown that civil society consists of two dimensions: institutional and discursive. In general, features of creation and arrangement of each of these dimensions are characterized. The functions performed by civil society in the European capitalist world economy are highlighted.
\end{abstract}

Keywords: the modern world-system, civil society, the European capitalist world-economy, communicative action, Geoculture of the modern worldsystem, capitalist class, French Revolution, urban middle class, model of liberal state, surplus value, lower strata, ideology of liberalism

Анотація. У статті пропонується поглянути на громадянське суспільство з позицій світ-системного аналізу Імануїла Валерстайна. Звичайно, Валерстайна навряд чи можна назвати теоретиком громадянського суспільства. Однак в його роботах наявні теоретичні положення, які стосуються й цієї тематики. У статті запропоновано потрактування громадянського суспільства як можливо третього структурного елементу модерної світ-системи, який, разом 3 двома іншими структурними елементами - осьовим поділом праці та державою і системою міждержавних відносин, - впорядковує соціальні відносини в ній. Показано, що громадянське суспільство складається 3 двох вимірів: інституційного та дискурсивного. У загальних рисах охарактеризовано особливості створення та влаштування кожного з цих вимірів. Виокремлено функції, що їх виконує громадянське суспільство в європейській капіталістичній світ-економіці.

Ключові слова: модерна світ-система, громадянське суспільство, європейська капіталістична світ-економіка, комунікативна дія, геокультура модерної світ-системи, капіталістичний клас, Французька революція, міський середній клас, модель ліберальної держави, додаткова вартість, нижча страта, ідеологія лібералізму.

\footnotetext{
${ }^{1}$ National Pedagogical Dragomanov University. n.bulatevich@ukr.net
} 


\section{Introduction}

This article is devoted to civil society as a subject of contemporary importance. This topic is widely developed in social sciences. Social scientists have created a number of theories of civil society, each of which offers its particular image. But many of such theories have one thing in common. Often civil society is considered in them as a structural element of a more general object - a modern society, - and depicted as emerging and developing within modern society. This feature is typical, for example, for the theory of civil society by Jürgen Habermas [19] or, for example, for Jeffrey Alexander's civil society theory [1] but also for other theories as well.

Immanuel Wallerstein in his world-systems analysis proposes a new object in the context of which social reality may be investigated. And this object is not a modern society, but - a world-system. Wallerstein distinguishes several types of world-systems that existed in certain historical periods. But the modern world-system the American scientist calls as the European capitalist world-economy. The world-systems approach creates new perspectives for interpreting the essence of civil society. Although it is difficult to consider Immanuel Wallerstein as a civil society theoretician, nonetheless, in his scientific studies, it is possible to distinguish theoretical provisions that concern this topic as well. They give grounds to consider civil society as a structural element of the European capitalist world-economy and from this angle to interpret peculiarities of its constitution and functions it performs. Such an interpretation can enrich knowledge about civil society developed in social sciences.

Accordingly, the purpose of this article is: based on the theoretical provisions of Immanuel Wallerstein's world-systems analysis, in general terms to outline the concept, peculiarities of constitution and functions of civil society as a structural element of the modern world-system. Considering the limited space, this article is rather fragmentary and schematic. The theoretical basis for this work is the world-systems analysis by Immanuel Wallerstein. However, it still lacks some specific conceptual-categorical instruments relating to the subject of civil society. Therefore, in order to reveal peculiarities of constitution of civil society as a structural element of the modern world-system, the concept of communicative action is used in the work. It is borrowed from the theory of communicative action by Jürgen Habermas, but it is used in the context of Wallerstein's world-systems analysis.

To reveal the subject of our study, the "structure - action" construction would come in handy. Structures organize social action, preventing it from unfolding in a random way. They channel, more or less firmly, social action in a certain direction, and do not let it steer away from the required course. Structures are historical formations. According to Wallerstein, they occur at a certain historical moment, develop for a more or less long period, and at some moment, they die out $[13,3]$.

This article consists of four points: 1) the first point summarizes the concept and main features of civil society as a structural element of modern society; this generalization is needed in order to depart from it and move to understand civil society in a world-systems perspective; 2) the second point employs certain provisions of Immanuel Wallerstein's world-systems analysis as the basis to show the peculiarities of creating the institutional dimension 
of civil society; 3) the third point employs certain provisions of Immanuel Wallerstein's world-systems analysis and the concept of communicative action to review the features of the discursive dimension of civil society; 4) and finally, the fourth point deals with the peculiarities of inclusion of the lower strata of the modern world-system into civil society.

\section{The concept and general features of civil society as a structural element of modern society}

In social sciences, the essence of civil society is often contemplated within the confines of a territorially limited social unit termed as "modern society". Civil society constitutes a structural element of this unit, distinct from its other two basic structural elements, economy and the state. Each of the three is interpreted as an autonomous sphere developing according to its own inner logic. On the one hand, economy, the state and civil society confront each other, but on the other hand, they supplement each other in their functions, thus stabilizing each other and forming the "systemic frame" of modern society $[1,31-33]$.

Economy is considered as a sphere of economic action. Within its framework, purposive-rational economic relations are ordered to create and distribute surplus value, or wealth. The state represents a sphere of administrative action. It features purposive-rational relations concerning distribution and exercising of administrative powers. Civil society is interpreted as a sphere of communicative action. This is a domain of communicative relations - an open rational communication that has the purpose of achieving the mutual understanding or consensus about how to organize common, collective life based on universal principles of justice [9, 217-219; 10, 318-319].

Based on Nancy Fraser's work, we can distinguish the following features of civil society: it territorially coincides with legally defined boundaries of a certain modern society; as a result of communication, it produces public opinion addressed to the state that exercises sovereignty over this territory; the subjects of communication are members of a legally constituted political community - nation, i.e. citizens of the state who can join voluntary nongovernmental and noncommercial associations, organizations and movements; every citizen has the same right to participate in communicative processes as other citizens; communication is implemented via national mass media, which connect territorially scattered participants with each other; communication requires the existence of a common linguistic medium: official language or several official languages [7, 10-12].

Civil society functions in a way that attracts attention to actions, events, states of affairs, etc. that, occurring in particular spheres of modern society, cause injustice. Citizens of the state "become outraged" and enter communicative networks of the public sphere to comprehensively discuss these actions, events and states of affairs in order to reach a consensus on the attitude to be displayed toward them and find the ways to fix the situation. As a result, civil society generates public opinion and uses it to put pressure upon administrative apparatus of the state and force the latter to adopt and carry out decisions aimed to restore justice. By participating in communicative processes 
of producing public opinion, citizens of the state become convinced that they have real influence upon organization of social relations in particular social domains. Society becomes for them their own "lifeworld" that they constitute for themselves, and the feeling of belonging to the same national community becomes stronger among them, thus strengthening social solidarity.

When conceptualizing the nature of civil society, it is important to establish when it has emerged, where and why. To ascertain these aspects, the concept of "European civilization" or simply "Europe" is often used in social sciences to define a historical-cultural formation that creates a single general cultural context for countries of the geographical region of Western Europe. As Andre Gunder Frank showed, an explanatory scheme is developed, according to which, European civilization rises in Ancient Greece and then passes a number of historical eras or stages in its development: antiquity, Hellenic-Roman, medieval, Renaissance, and early and late modernity $[6,3]$.

According to this scheme, the origins of civil society are also rooted in Ancient Greece. At that stage, it is its "protoform". As European civilization has been developing, other protoforms of civil society have occurred in the context of subsequent eras. And only in era of early modernity did it begin to attain its present form. This explanatory scheme is often reproduced in works by social scientists. An example is works by the civil society historian John Ehrenberg [5] or the political scientists Steven DeLue and Timothy Dale [3]. The key factor that gave impetus to the emergence of civil society in early modern age was capitalism that was born at that time. The appearance of capitalism itself is also attributed to the cultural context of European civilization and traditionally explained, following Max Weber, by the effect of the ethics of ascetic Protestantism.

Speaking about particular countries of European civilization, civil society has first emerged in England and France in the $17^{\text {th }}$ century, because capitalism was beginning to spring up in these particular countries. The terms denoting the new communicative sphere were coined at that very time: English "civil society" and French "la société civile" $[19,46]$. How does capitalism give rise to civil society? To ensure rational functioning, capitalism needs to institutionalize itself in the relevant social structures of the society. At the time of its birth, these were nonexistent in the "still-feudal" world of the $16^{\text {th }}-17^{\text {th }}$ centuries. Therefore, having been born in England and France, capitalism set in motion modernization processes in the "traditional" societies of these countries. It caused rationalization and differentiation of these societies, and as a result, old feudal structures started to gradually come down and give way to new, separating from each other, basic structures necessary for the capitalist order: modern economy, the state and civil society. Social transformations in England and France continued for several hundreds of years, completing only in the mid- $19^{\text {th }}$ century. A rational form of capitalism and the corresponding modern societies with differentiated economy, the state and civil society gained a firm foothold in these countries.

In other countries of European civilization, social changes were launched somewhat later, depending on when a particular country began to switch to the "capitalist footing". In Germany, for instance, it began in the $18^{\text {th }}$ century. And by the early $20^{\text {th }}$ century, in Max Weber's opinion, countries of Europe have completed the transition to rational capitalism and saw the rise of develo- 
ped modern societies in their territory $[18,255]$. The French Revolution played an important role in these processes by helping eliminate obsolete feudal social structures and entrench new, modern ones.

After modernization of European countries finished, capitalism began to be considered not a unique phenomenon rooted in the culture of European civilization but a universal factor of successful development. As Wallerstein shows, there was now a belief that it could be implemented in any place of the world, even if the required cultural context was absent there. All an undeveloped country had to do is to start the necessary reforms and begin developing a European-like capitalism, and that would immediately set in motion modernization processes resulting, at the end of the day, in the establishment in that country of a developed, rationalized modern society [13, xviii].

However, there were instances when in certain countries the processes of capitalist modernization were launched but then curbed at certain point, for one reason or another, or when their "catching-up" modernization had from the very beginning an alternative, "non-capitalist" character. In those instances, developing a rational capitalism is not possible. In the societies of these countries, the three base modern structures do seemingly appear, but their sufficient differentiation could not be achieved. There is often a situation when the state towers above the other two spheres, intruding on them and subordinating them to the logic of its development. Countries like that see the establishment of a nondemocratic (e.g. authoritarian or totalitarian) political regime. Private sector-driven market economy begins to degenerate, and the functioning of civil society is defined and controlled by the state, which is manifested, in particular, in the control by the state of the topics for communication and of the arguments that should be used in that communication.

If a country begins transition to capitalism and moves toward development of the necessary social structures but transformations have not been completed yet, there might be another situation in which the economy towers above the other base spheres of action and subordinates them to the logic of its development. Under these conditions, the country sees the establishment of a not-quite-rational form of capitalism, the so-called "wild capitalism". The state is reduced to the minimum, performing only the limited functions of a "nightwatch". Communication in the civil society domain becomes fragmentary and reified under the pressure from an uncontrolled and unregulated market, and the mechanisms for communicative producing of public opinion fall apart. In both cases of insufficient differentiation - when either the state or economy dominates over the other two spheres - civil society cannot be considered sophisticated. Free rational communication in it degrades, the possibility of achieving mutual understanding in a communicative way becomes more difficult, and social solidarity weakens.

Immanuel Wallerstein proposes orientation not toward the modern society but toward a more global object - world-system. The scholar calls the modern world-system a European capitalist world-economy. It has emerged in Europe during the "long $16^{\text {th }}$ century", went through several waves of territorial enlargement since then, and eventually, encompassed the entire world. A world-economy has many political units and cultures within it, and daily life of people in it is substantially different, but at the same time, it remains an integral formation knit on the basis of single economy. The underlying sys- 
temic principle for development of the world-economy is infinite accumulation of capital [17, 85-86].

A world-economy consists of two structures. The first is the axial division of labor. According to Wallerstein, it contains three production regions characterized by an uneven degree of development: core, semiperiphery and periphery. The axial division of labor orders economic action within a worldeconomy. The production region of periphery creates conditions for directing economic action into the channel of producing raw materials with low surplus value, while in the core region, it is directed into manufacture of industrial high-tech products with high surplus value. In this respect, the semiperiphery occupies an interim place between the other two. After exchanging the core's industrial high-tech products for the periphery's raw materials, surplus value flows, with intermediation of the semiperiphery's "conveyor belts", to the core and accumulates there. That's how the mechanism of exploitation by core countries of the workforce and raw materials of periphery countries is formed, with simultaneous strengthening of the latter's underdevelopment $[13,86-87$, $116,219]$.

The other structure of a world-economy is represented by states and interstate blocs where administrative action takes place. Core countries have strong states that maintain the domination of the core over the periphery. They facilitate uneven redistribution of surplus value among production regions. At the same time, core states wage a continuous struggle among them for the right to exploit the periphery and control the semiperiphery. Peripheral countries have weak states that have little to confront "core" states with. Their role is being reduced to the balancing of the local budget and maintaining social order in the territory they control. Based on these two structures, elites of "core" states become able to appropriate the overwhelming proportion of surplus value produced in a world-economy [14, 113-116].

Considering peculiarities of the constitution of the modern world-system, Wallerstein is talking only about two structures of that system: 1) axial division of labor and 2) modern states and interstate system. Still, the worldsystems analysis of the American scholar contains theoretical provisions that give reasons to think about whether civil society can be considered the third structure of a world-economy. According to its definition, civil society is a sphere in which communicative action is institutionalized. And if it indeed is the third structure of the modern world-system, communicative action in it must be institutionalized in a way that does not contradict the logic of the worldeconomy's development: communication in civil society must promote, directly or indirectly, infinite accumulation of capital.

Wallerstein's approach may have some consequences for the interpretation of historical development of civil society. The concept of "European capitalist world-economy" is ill-aligned with the concept of "European civilization". If we are to imagine social world as a world-economy, then, firstly, it would be economy that brings social world's components into a single whole, not a single cultural context. And secondly, the beginning of this world is dated to the "long $16^{\text {th }}$ century" and not earlier. Social worlds that existed in the geographical region of Europe before the appearance of the world-economy can be regarded as other, distinct historical systems rather than development phases of the single whole called "European civilization". Therefore the view claiming that 
civil society is inalienably related to the development of "European civilization" and traces its origins to Ancient Greece does not look convincing.

On the other hand, the concept of "European civilization" does not take into account development specifics of communicative sphere in other regions of the world. There are studies showing that, for example, in Imperial China under the Ming and Qing dynasties, this sphere was more developed than in contemporary Europe. For instance, Karla Simon [11], Michael Edwards [4, 255], Kathryn Bernhardt, Philip Huang and other scholars [2] describe not only a great diversity of voluntary organizations in Chinese cities, such as public hospitals, market associations, cultural groups, public homes for the elderly, etc. that were cared for by the townspeople themselves, but also the existence of elements of the legal system that regulated their activity. In all likelihood, communicative relations existing in the public space between economy and the state can be found in any developed historical system; they just take a different shape in each of them. One can assume that in the modern world-system, they take the shape of civil society.

The other consequence is reinterpretation of the reasons for the emergence of civil society. In his world-systems analysis, Wallerstein shows that capitalism is an attribute of a world-economy, not of particular units that form it. A worldeconomy is what's capitalistic, not the countries existing within it. What we can say about these countries is that they are, for instance, more developed or less developed, depending on the place each of them occupies in the axial division of labor: in the production region of core, semiperiphery or periphery. Capitalism cannot be built in a separate country, and therefore, it cannot be a factor directly responsible for the appearance of modern society in a particular country, of which civil society is an inalienable structural element. If we are to adhere to this view, sophistication or unsophistication of civil society in a particular country should be explained by other factors.

From the standpoint of Wallerstein's world-systems analysis, the answers to the questions of the time, place and reasons for emergence of civil society become more precise. A modern civil society has emerged between 1789 and 1848 in core states of the modern world-system. Since the world-economy emerge during the "long $16^{\text {th }}$ century" and civil society has appeared in the late $18^{\text {th }}$ - early $19^{\text {th }}$ century, it appears that the world-economy has successfully existed without this structure for almost three hundred years and did not need it for its development. Why then has civil society emerged, after all? An indirect cause was, of course, development of the European capitalist world-economy, but the event directly responsible for its emergence was the French Revolution.

In social sciences, civil society can be considered consisting of two interrelated dimensions: institutional and discursive. This approach is employed, for instance, by Jeffrey Alexander [1, 69]. The institutional dimension is related to social institutes that create conditions for deployment of open communication in the society, while the discursive dimension to the cultural knowledge, codes and symbols used directly during communication. When taking a look at civil society from the standpoint of world-systems analysis, this approach can be used as the basis to describe its constitution. But now, the specific features of both the institutional and discursive dimensions would be interpreted somewhat differently. 


\section{The French Revolution and the establishment of the institutional dimension of civil society}

The French Revolution was, undoubtedly, an event that significantly changed today's world. Social sciences offer enough explanations of its meaning, causes and effects. A distinguishable feature of Immanuel Wallerstein's version is the consideration of the French Revolution in the context of development of the modern world-system. As follows from the very definition of the European capitalist world-economy, the French Revolution could not, by its very essence, be "bourgeois" in the sense that it caused, or at least accelerated, the transition from feudalism to capitalism, because at the time it broke out, capitalism has been successfully functioning for quite a while.

Randall Collins showed that thanks to the efforts from Theda Skocpol, Charles Tilly, Jack Goldstone and other scholars, an explanatory model has been developed, citing intra-elite conflict that results in a collapse of the state as the main reason for modern revolutions. According to this model, a revolution always starts "on the top", among the elite. In order for it to happen, two key factors must coincide. The first is fiscal crisis of the state: the state finds itself in a situation when it is no longer able to pay foreign debt or finance its own army, police and security forces. Fiscal crisis is often caused by military reasons: exuberant military expenditures and battlefield defeats. However, it becomes fatal when combined with the other factor - a split among the elite as regards the way out of the difficult situation. When an intra-elite conflict escalates to the point when any agreements and at least the minimal consensus become impossible, the state machinery becomes paralyzed and the monopoly for the legitimate use of force falls apart. That opens the door to the spontaneous popular uprising and the overthrow of the ruling regime $[12$, 57-58].

Overall, Wallerstein's description of the French Revolution fits into the aforementioned model. However, the context of the modern world-system is added. A world-economy is developing in a way that, on the one hand, it goes through a number of economic upturns and downturns explained by Kondratyev's theory of long cycles, and on the other hand, hegemon states appear within it from time to time. The latter play an important role in its development, being capable of ensuring relative stability and order in a world-economy, but their hegemony does not last long. When a hegemon steps down, a fight for the vacant position ensues. From that moment on, the order in a worldeconomy becomes shaky. A long period of disorder and turbulence begins, featuring protracted world wars.

According to Wallerstein, after the United Provinces of the Netherlands lost the status of hegemon in 1675 the struggle between Great Britain and France for hegemony began, culminating in the Seven Years' War. France was defeated in that war, which essentially meant losing the struggle. And in the early $19^{\text {th }}$ century, Great Britain became a hegemon state of the modern worldsystem. For France, the consequences of the defeat were severe. Its position in the world-economy became worse. The loss of key colonies combined with large military expenditures undermined France's financial strength. The balance between revenues and expenditures was upset, and the country was forced to borrow more and, thus increasing its sovereign debt. As of 1788, the costs of 
servicing sovereign debt have reached $50 \%$ of the country's budget, and the state has found itself on the verge of bankruptcy [15, 84-85].

Wallerstein shows that in the early 1770s, French elites (although the American scholar was talking mostly about the capitalist class, attaching somewhat lesser significance to other elite groups) began to look for ways to improve the difficult financial situation. Two competing options have been proposed. Capitalists-manufacturers saw the most effective solution in the substantial increase of taxes levied upon agricultural enterprises of capitalistslandowners. These taxes were traditionally low, for the latter enjoyed tax benefits guaranteed by their nobility status. On the other hand, capitalistslandowners opposed the implementation of any mechanisms that could redistribute their profits in favor of the state. They saw the way out of crisis in liberalization of trade. Capitalists-landowners have managed to lobby a trade agreement with Britain, signed in 1786. According to that agreement, France opened its domestic market to British industrial goods, while Britain opened its market to French agricultural products. They hoped to replenish public finances with customs receipts from duties levied upon imported industrial goods. However, no substantial improvement of financial situation could be achieved $[15,86-88]$.

Instead, the position of capitalists-manufacturers has worsened as they have been squeezed out by British competitors from not only foreign markets but even France's domestic market. Capitalists-manufacturers were unceasingly pressuring the state, demanding drastic measures: promoting stronger their interests within the world-economy, substantially enlarging the tax base, erecting customs barriers to protect local manufacture and trade against foreign competition. On the contrary, capitalists-landowners opposed restrictive economic and trade measures and measures aimed to strengthen the state, rejecting the raise of taxes and insisting upon continuing liberalization. They have even been seriously thinking about the option of rolling France back to the semiperiphery, considering the possibility of the country's partial deindustrialization $[15,89-92]$.

By 1789, France's public finances have reached the critical condition. Yet, no program of getting out of this situation could be developed. At some moment, exasperated by acute fiscal crisis, the intra-elite conflict has reached the highest point of escalation. The state became dysfunctional. The mechanisms of the legitimate use of force malfunctioned, and a vacuum of power has appeared in the society. The dam was destroyed, and the waves of broad masses poured into the breach - a revolution in France has begun. And the rising masses of people - the lower strata and urban middle class - appear at the historical stage.

The broad masses have directed their revolutionary energy toward radical redistribution of surplus value in their favor. The masses wanted to destroy the world-economy's structures and mechanisms that made infinite accumulation of capital possible. Therefore, Wallerstein believes, the French Revolution had an anti-system, not "bourgeois" nature. Since the explosion has occurred in a key core state, the legitimacy of the world-economy faltered and revolutionary uprisings began spreading over the countries of both the core and other production regions. 
In the course of the French Revolution, the rising masses demanded to shift the locus of sovereignty from the monarch to the people. In practice, that meant transformation of the state from an absolute monarchy to a popular democracy. If these demands were met, the broad masses would have received control over the state and, along with it, real instruments for redistribution of surplus value, while the capitalist class would have lost both the power and the possibility to continue accumulating capital infinitely. On the one hand, the capitalist class had to heed to demands of the rising people. But on the other hand, they could not allow the establishment of a popular state. To find the way out of this problematic situation, the capitalist class had, Wallerstein believes, to show wits and inventiveness. They had to design a model of the state that would appear popular at first glance while not actually being such, but even then enjoying support from a substantial part of the population, and the establishment of such a state would have calmed down the revolutionarilyspirited population. The historical solution was to create the model of liberal state, which eventually replaced the absolute monarchy [16, 23].

The arguments cited by Wallerstein give reasons to assume that the model of liberal state envisages the establishment of not only a modern liberal state allegedly facing the people but also civil society. Open communication in the sphere of civil society enabled the public to legally exert influence over the state, compelling the latter to take certain measures. On its part, the state was becoming accountable to civil society, orienting toward its demands; decisions made by the state had to conform to the will of the people. This was the scheme through which the "popular" nature of the new model of state had to be realized. But in fact, this model made possible only a limited participation in the discussion of a quite narrow range of local matters. The implementation of this model did not change the position of the capitalist class and did not alter the fundamental principles on which a world-economy is developing. Still, it did receive the support from the people, or at least from their key part, urban middle class.

The establishment of a new model of state began with constitutional and electoral reforms in core states. The adoption of constitutions limited the monarch's powers, while enfranchisement of the people enabled them to elect legislative bodies of the state. The next step was introduction of broad civil rights. The equality before law, freedom of movement and choice, freedom of speech, expression, conscience, religion and belief, freedom of association and freedom of information - all these liberties made possible public discussion of contemporary political, economic and other matters. Reforms led to the creation of the foundation for the model of liberal state - the nation of citizens.

The establishment of the model of liberal state was accompanied by the de-facto constitution of civil society's institutional dimension, which became the foundation for open public communication. A number of civil society institutes can be named. The first important institute is public opinion, the production of which was legally enabled and legislatively regulated. The second institute is, probably, the liberal state, which is subjected to communicative pressure from public opinion and must react to it. A modern civil society could hardly be able to function without the existence of a liberal state. Free and independent mass media enabling communications to circulate across the entire society and expanding the public sphere should be included to civil society 
institutes as well. The system of civil rights, and especially the right to vote, is also worth mentioning. Perhaps, it makes sense to include to civil society institutes voluntary associations, organizations, parties, etc. legally established by citizens and legislatively regulated.

Development of the new model was distinguishable for the fact that at first, electoral and civil rights have been unequally granted to the urban middle class and the lower strata. Emmanuel-Joseph Sieyès proposed to differentiate between "active" and "passive" citizens. In his opinion, all people living in the country had to have the right to life, the right to protection of their person and property, the right to freedom. However, not everyone should have the right to form bodies of public administration and participate in open communication in the civil society sphere, i.e. not all are "active" citizens. According to Sieyès's terminology, only representatives of the urban middle class have the status of "active" citizens [16, 145].

Having gained the right to vote and the right to legally participate in communicative processes of producing public opinion, the urban middle class became confident that they really have influence upon organization of social life and that they do determine the direction of its development. They abandoned revolutionary practice, making themselves comfortable within the new sociopolitical order of "modern society". After that, uprisings of the lower strata lost their edge and no longer posed a serious threat. Without network and organizational resources of the urban middle class, anti-system rebellions of the lower strata had little chances to succeed. The only thing left for the lower strata was to be content with the questionable status of "passive" citizens $[16$, 73-75].

According to Wallerstein, the establishment of the model of liberal state in three core countries of the European capitalist world-economy: Britain, France and Belgium, was completed in 1830-1832 [16, 74-75]. The urban middle class became the main adept and support of this model. At first, only representatives of this class were included to civil society as full members or participants. The model of liberal state provided structural stability to the modern world-system and restored its lost legitimacy. The new model became a template for political changes, and over time, it was implemented, to a greater or lesser degree of success, everywhere within the modern world-system.

\section{Geoculture of the modern world-system and the discur- sive dimension of civil society}

The creation of institutional dimension enabled to organize and to order circulation of public communication streams in society. However, the institutes themselves were not enough. In order to establish communication, the very communication between citizens must be channeled in a certain direction. For that purpose, the second - discursive - dimension of civil society must be constituted in a special manner. Any communication is based on a language, and language, in turn, is deeply interwoven into the cultural environment of a community and is formed in it. Therefore, the discursive dimension of civil society requires the existence of a special language of communication and the relevant cultural context. Wallerstein's world-systems analysis does not have 
enough instruments that could be used to study the discursive dimension, but Jürgen Habermas's theory of communicative action does - it's the concept of communicative action. It can be used to perceive the discursive dimension of civil society while adhering to the world-systems view at social reality.

Jürgen Habermas has developed the notion of communicative action to cognize the domains of social reality that Max Weber's attention missed. Habermas understands communicative action as a special type of social action. It is realized in a dialogue and takes the form of linguistic utterances in which the actors or participants of dialogue are trying to reach mutual understanding as regards something in the world and coordinate their behavior on that basis. Acting communicatively, every participant offers an own vision of the problematic situation being discussed, criticizes the vision of others and defends his own vision against objective criticism, and that goes on until all actors arrive at the common definition of situation. In communicative action, mutual understanding is achieved on the basis of rational argumentation: a participant may drop his own interpretations and accept interpretations proposed by others not because of external coercion but voluntarily, yielding to the power of better arguments [9, 10-13].

When trying to reach mutual understanding, actors always assume relation to something in the world. Habermas offers a decentered understanding of the world, dividing it into three formal domains: objective world of existing states of affairs, social world of the community of which the participants of dialogue are members, and subjective world to which only one person has privileged access. Acting communicatively, actors may refer in their utterances to things from one or another world: to objective facts of nature, to social norms and values of the community, or to their own subjective experiences. The three worlds distinguished by Habermas represent differentiated segments of the knowledge used in communication [9, 52].

If, during communication, an actor assumes relation to the objective world, his communication is represented, according to Habermas, by constative utterances in which he refers to facts and represents the existing state of affairs. An actor states something about the physical world of nature, and is able to defend the truthfulness of his utterances in the light of objective criticism. Truth becomes the criterion for evaluation of utterances: other actors may accept or decline a statement on the basis of whether or not it represents the true state of affairs. If an actor assumes relation to the social world of the community whose member he is, his communication would then be represented by regulative utterances. In these utterances, he refers to social norms and values and establishes interpersonal relationships with other members of the community. An actor puts forth the imperatives regarding how others should conduct themselves, or defends the conformity of his own behavior with the community's legitimate norms. In that case, normative rightness becomes the criterion for evaluation of utterances. And finally, if an actor assumes relation to his own subjective world, he makes expressive statements referring to his personal subjective experiences and presents his self to others. An actor is trying to create a certain image of himself in eyes of the public by randomly revealing his own subjectivity. The criterion for evaluation of utterances in this case is sincerity [9, 85-88, 90-93]. 
According to Habermas, communicative action envisages language as a medium for free communication, in which actors simultaneously refer in their linguistic utterances to things in the objective, social and subjective worlds in order to establish a common definition of the situation and reach mutual understanding this way. Acting communicatively, actors integrate the three worlds into a single coordinate system that provides them with the knowledge for interpretations. They simultaneously refer to objective facts, social norms and values, and subjective experiences and mutually put forth validity claims for the truth, normative rightness and sincerity. Ideally, communication should produce an inter-subjective meaning of the world that is the same for all participants [9, 93-95].

The social world plays an important role in the daily communication practice. In their interpersonal relationships, actors continuously face problematic and often conflict situations that require resolution. The resolution takes place via the reference to the social norms and values legitimate for the particular community. If actors assume relation to the social world in daily communication, their communication may be channeled into two different discourses. Habermas calls the first of them a "discourse of application". In it, the participants of communication refer to social (in particular, moral) norms without thematizing them [8,67-68].

The second discourse unfolds in a situation when actors thematize and discuss the norms per se, trying to arrive at the common understanding of these norms or to establish new norms. In that case, actors refer in their arguments to the social values that are significant for the community. Interpreting, establishing or abolishing a particular (including legal) norm is possible on the basis of values. The latter lay at the core of social norms that regulate daily behavior in the social environment. Habermas calls this discourse a "discourse of justification". It is important that values must be internalized by every member of the community and transformed into internal structures of his conscience. A communicative establishment, interpretation or abolition of a norm within the "discourse of justification" may be possible only under this condition, and a proposal to act in accordance with a particular social norm as part of the "discourse of application" will not be construed as external coercion $[8$, $67-68]$.

Communicative always occurs in the horizon of lifeworld. Daily communicative practice takes place against the background of lifeworld, and in turn, lifeworld is reproduced via interpersonal communication. One cannot exist separately from the other. Habermas understands lifeworld as the context for the processes of achieving mutual understanding, as the background for thematizing and discussing particular problematic situations in daily life. The German scholar distinguishes three structural components of lifeworld, terming them as "culture", "society" and "personality". For Habermas, "culture" means the stock of knowledge from which participants of communication draw interpretations; "society" means legitimate orders through which the participants regulate their membership in a social community and reproduce social solidarity; and "personality" means competencies enabling the subject to speak and act, i.e. enabling him to participate in the processes of achieving mutual understanding [10, 135-138]. 
Since civil society is defined as an institutionalized sphere of communicative action communication in civil society takes place according to the rules of that action. Citizens of the state communicate in order to achieve mutual understanding on the basis of rational argumentation. They broadly use the knowledge from all three worlds, referring in their utterances to facts, social norms and values, and subjective experiences, mutually raising validity claims for the truth, normative rightness and sincerity. However, civil society is a special sphere. Communication in it is somewhat different from the one taking place in ordinary daily life. In civil society, the purpose of communication is to achieve understanding regarding not simply narrow, limited "routine" problematic situations but also bigger matters - the matters of rational, correct organization of society in general and its certain domains in particular. Therefore, relation to the social world and the use of appropriate knowledge play the key role in this respect. But the very stock of that value-based normative knowledge to which citizens could refer must be special.

On the other hand, the model of liberal state was designed to become implementable in any core, semiperipheral or peripheral state. This model became standard, or template, for countries of the modern world-system after the French Revolution. Since civil society is established along with the establishment of a liberal state, it must be standard, too. It must be characterized by the same attributes, regardless of the world-economy country in which it occurs. It means that besides standard social institutes, the value-based normative stock of knowledge or, in Habermas's words, the component of lifeworld called "society", must the same everywhere, too. No matter what production region of the modern world-system a country is located in, no matter what its cultural specifics are, what language its people speak and what religion they follow, but if this country adopts the model of liberal state, it must see the establishment of a standard value-based normative cultural context that enables standard communication in the civil society domain. And first of all, we are talking about the uniform set of values that must be internalized by the country's people.

It appears that Geoculture of the modern world-system was responsible for ensuring such a uniform value-based normative filling of the discursive dimension. It created the same stock of knowledge about the social world, or "society" component of lifeworld, for civil societies of any country of a worldeconomy adopting the model of liberal state. In Wallerstein's opinion, Geoculture of the modern world-system is the ideology of liberalism. It shaped itself up in the course of the French Revolution, and has finally gained foothold before 1848. Geoculture contains a system of values that are essentially ideological. They include, first of all, freedom, equality and justice, and a number of other, derivative values, in particular, tolerance, dignity, individual autonomy, development of human abilities, etc. Geoculture of the modern world-system enabled to transcend cultural and religious specifics of the population of any country and create in that country, along with the relevant social institutes, a standardized, modern rational community: civil society.

Regardless of what matters of the society's constitution citizens were trying to reach understanding on in the public sphere, they would refer in their expressions to the standard set of values of the "common social world". 
It results in relative standardization of communication itself. It becomes sufficiently defined or canalized, flowing in a more or less defined direction. The channeling of communication also manifests itself in the fact that a person referring to alternative values may be labeled "uncivil" and, in the best-case scenario, pushed back to the "periphery" of civil society or, in the worst case, expelled from it. When communication concerning the constitution of society takes place, a predetermined set of values helps build, regardless of the region of a world-economy, approximately the same image of a properly-organized rational society: open, just, equal, etc. It must be oriented at in civil communication. The actually existing societies are still far from this image, so they have to be "approximated" to that image on the basis of civic engagement and activity.

Geoculture of the European capitalist world-economy enabled to standardize communication in the civil society domain, bringing communication to a "common denominator". So now, public communication in civil society of any country of the modern world-system was taking place in a more or less the same way, according to the same rules. Overall, the establishment of the model of liberal state convinced the urban middle class that they have received real control over the state and the ability to influence decisions the state makes. They were assured that they now have an efficient instrument of improving the existing, still imperfect society.

From now on, any injustice, any "defects" in the society could be fixed peacefully, via open public communication in civil society, by producing public opinion as a result of communication and exerting pressure upon the liberal state. It seemed that one of the important postulates of liberalism, spoken about by such thinkers as John Locke, James Harrington and Immanuel Kant, has finally been put into practice: a nation of citizens is able themselves to set the course of development of their society via open, public communication and via broad use of "communicative reason"; a nation is able to gradually direct the society, step by step, toward a more developed, ordered, rational state. To be sure, that would require a relatively long time to accomplish. Instant changes are impossible. But in a distant future, a society guided by the will of its citizens would definitely become more and more just and rational. Radical, revolutionary methods of social changes are not only inappropriate and irrelevant but also dangerous and harmful. Looking from the angle of Wallerstein's world-systems analysis, it appears that the construction "liberal state - civil society" has become a sort of a mechanism used by the elites of the modern world-system's core states to suppress anti-system rebellions of the lower strata via limited engagement of the urban middle class in political administration processes.

\section{Peculiarities of inclusion of the lower strata of the European capitalist world-economy into civil society}

In the course of revolutionary events, the urban middle class and the lower strata fought together to overthrow the absolute monarchy. However, their union broke up after adoption of the model of liberal state. The new model did not quite conform to interests of the lower strata - they wanted more radical 
transformations. But the urban middle class believed that the main goal of revolutionary movement had been achieved, and blocked further development of anti-system rebellions. The model of liberal state became a reality of life, so the lower strata had to get used to it. However, the urban middle class began to oppose the broadening of electoral and civil rights: having achieved full membership in civil society, they looked for the ways of not letting the lower strata in it. In that respect, their interests coincided with interests of the capitalist class of the modern world-system, who also could not accept the idea of political participation of the lower strata.

The problem was how to justify the exclusion of the lower classes without contradicting ideological achievements of the French Revolution: the principles of freedom, equality and justice. Immanuel Wallerstein shows that a special criterion was applied to justify the exclusion of the lower strata, the so-called "reason" criterion $[16,7]$. The ability to act reasonably was named the key condition for participation in communication in the civil society sphere. Only if the participation is limited to those who have this ability would the communicatively achieved agreement regarding the ways of correctly organizing social life become possible. But who should be considered "reasonable", or worthy to partake in civil communication?

Jeffrey Alexander notes two polar discourses appearing in the communicative field of civil society: "discourse of liberty" and "discourse of repression", based on the system of binary symbolic codes. If a social group is constituted in positive symbolic codes of the "discourse of liberty", its representatives are depicted as having the qualities required for participation in communicative processes of producing public opinion: they are rational and critical, and do not require strong "leaders" and do not submit to authoritativeness; they are autonomous, abiding by law not because of external sanctions but because law expresses their natural rationality; they make themselves clear and do not conceal their ideas; they are open and benevolent to other members of a social community, etc. Representatives of this group do meet the criterion of "reason", and therefore, can be included into civil society [1, 56-59, 60-61]. At first, only the representatives of the urban middle class were depicted in positive symbolic codes of the "discourse of liberty". Only they were considered sufficiently competent to partake in open public communication in the modern civil society.

The "discourse of repression" refers to "uncivil" qualities. If a social group is constituted in negative symbolic codes of the "discourse of repression", its representatives are depicted as threatening the existence of civil society. They are unable to make rational judgments and critically perceive information; they cannot tell truth from lies, and therefore, they are easy to manipulate; these people are dishonest, inclined to recognize the authority and thoughtlessly submit to it, etc. The representatives of this group do not meet the criterion of "reason", and therefore, must be excluded from civil society [1, 56-59, 60-61]. The lower strata was immediately placed under the "discourse of repression", in particular, the following three social groups: working class, women and the Blacks. The representatives of these groups were considered incompetent in the sense of the ability to participate in civil communication. Since they are hardly able to make a rational contribution to discussions concerning matters 
of contemporary importance for the community, particularly those concerning its rational constitution, they must be denied the membership in a modern civil society. Therefore, the model of liberal state envisaged from the very beginning that only a small fraction of people - white educated wealthy males - have the right to engage in open public communication.

After the establishment of modern civil society, social movements of those excluded from it began to appear in it. Worker movements, feminist and suffragist movements, movements of the Blacks oriented toward the use of communicative institutes of civil society in order to depict their social groups in positive symbolic codes of the "discourse of liberty" and substantiate on this basis the legality of their inclusion and the need for it. On the other hand, the dominant social groups - capitalist class and the urban middle class - wanted to apply the "discourse of repression" to the representatives of the lower strata in order to deny their access to the newly-established communicative sphere. Therefore, a lengthy symbolic struggle for the inclusion was waged in the discursive field of civil society.

Over time, main social movements would achieve success and "fade away". At least in core and semiperipheral states, the lower strata have eventually gained the electoral and broad civil rights: working class earlier, women and the Blacks later. But that did not significantly change their position in the capitalist world-economy. The lower strata were unable to achieve a substantial redistribution of surplus value in their favor, but only a partial one, based on mechanisms of the so-called "welfare state"; nor were they able to shake the power of the capitalist class. Instead, their rebellious energy was redirected from anti-system revolutions into the channel of struggle for the inclusion into civil society, thus being exhausted. And the integration of lower strata into national societies helped strengthen social solidarity, thus strengthening core states even more. The model of liberal state has been successfully functioning for a century and a half, and the first crisis has occurred in 1968.

An important function of civil society should be mentioned here. Civil society is a sphere where via rational communication meanings are produced. This function was discussed as by Jürgen Habermas, as by other scholars as well. In particular, it was described in Ralf Dahrendorf's works. This scholar says that in the modern era, people need deep cultural ties, the existence of which would give meaning to the world. These ties bind societies together, keep them in unity. Dahrendorf terms them as "ligatures". Without them, there is a danger to go down into the state of anomy. In Dahrendorf's opinion, civil society is the most important structure in society where "ligatures" are produced. Using civil communication, people provide themselves with semantic benchmarks in order not to feel themselves hapless in the ever-changing, unstable modern world [20, 32-36].

An assumption can be made from the standpoint of world-systems analysis that civil society of every country that adopted the model of liberal state produces more or less the same semantic benchmarks. In other words, communication in civil society gives the European capitalist world-economy uniform meanings. In particular, they help its residents reconcile with the injustice of social reality. These meanings are essentially ideological. They work well in core states, while their certain artificiality may be felt in peripheral states. 
But overall, they serve their purpose. Max Weber says that in the $16^{\text {th }}$ $17^{\text {th }}$ centuries, Protestant ethics that promised eternal bliss in the afterworld helped the lower strata reconcile with their dismal fate and quietly bear the burden of exploitation. In the $19^{\text {th }}-20^{\text {th }}$ centuries, the full-fledged inclusion of the lower strata into civil society and active communicative participation in it brought the hope that a more just social order could be created in the future with the efforts of the citizens themselves.

Immanuel Wallerstein forecasts that approximately in the mid- $21^{\text {st }}$ century, the European capitalist world-economy will cease to exist. The capitalist mode of accumulation of wealth, based on the axial division of labor, will exhaust itself. It is going to cause crisis of the other two structures, modern state and civil society. The ideology of liberalism will probably lose the status of Geoculture. It will become clear that social deficiencies of society could hardly be gradually fixed via rational communication. The fundamental issue of fair redistribution of surplus value may again take the center stage. A crisis of civil society, coupled with the decline of Geoculture of the modern world-system, may produce the situation of the lack of "ligatures" in which the "world" can lose sense. People may start looking for other mechanisms of producing meanings and for other cultural sources required for that purpose. Perhaps the first and the simplest thing in this situation would be to turn to religion. One of the possible ways out of the state of the "lack of meaning" could be rollback to religious fundamentalism.

A new world-system will rise in the place of the European capitalist worldeconomy. The mode of producing wealth and the mode of its appropriation by elites will probably change. The economy and the state will probably be organized somewhat differently. In that case, civil society may undergo transformation as well. The very communication in public space will not disappear, especially considering that information technologies would enlarge the public sphere like never before. However, both the institutional and the discursive dimensions of civil society may undergo some changes. Public communication may be ordered somewhat differently.

\section{Conclusions}

1. Modern civil society as the third structural element of the modern world-system appears in the context of political changes - changes caused by the French Revolution. It emerges along with the model of liberal state. Establishing of civil society made it possible to organize and to canalize in a definite direction a public open communication in the European capitalist worldeconomy.

2. Communication in public space outside the scope of the state and economy took place before the French Revolution as well, and it was typical for not just European countries but also, for instance, developed world-empires of East Asia. But only after the French Revolution have the necessary social institutes and the necessary value-based normative cultural context been created in the modern world-system, shaping public communication in the form of fundamental practices of modern civil society. 
3. Civil society is often considered an entity confronting the state and trying by all means to limit its authoritarian tendencies. At the same time, civil society needs the state for its normal functioning. But it must be a liberal state, not, say, an absolutist state. Civil society and a modern liberal state need each other and could hardly function separately from each other.

4. The growth of civil society enabled to redirect the rebellious energy of the broad masses from anti-system revolutions into the peaceful channel of civil communication. At the same time, the functioning of the European capitalist world-economy was not seriously disrupted. The very communication in civil society was strictly regulated and canalized in that direction and not in another.

5. Civil society is a controversial entity. On the one hand, its functioning enables citizens to influence the organization of their collective life; but on the other hand, its creation rather makes an impression of the possibility to exert influence, in the sense that it is limited by territorial borders of a national state. However, the processes taking place in the world-economy at the supranational level and having indirect, or even direct impact on life of the citizens, remain beyond their influence.

6. The urban middle class was the social group that benefited the most from the advent of civil society. The creation of a new communicative sphere was very much in their interests. Unlike the lower strata, they were not interested in more radical political changes. Therefore, anti-system rebellions of the lower strata were transformed into liberal or national bourgeois revolutions largely thanks to the efforts of the urban middle class.

\section{References}

[1] Alexander, J.C. 2006. The Civil Sphere. Oxford: Oxford University Press. $793 \mathrm{p}$.

[2] Bernhardt, K. and P.C.C. Huang, eds. 1994. Civil law in Qing and Republican China. Stanford: Stanford University Press. 340 p.

[3] DeLue, S.M. and T.Dale. 2016. Political thinking, political theory and civil society. 3rd ed. New York: Routledge. 388 p.

[4] Edwards, M. 2014. Civil society. Cambridge: Polity Press. 185 p.

[5] Ehrenberg, J. 1999. Civil society: the critical history of an idea. New York: New York University Press. 285 p.

[6] Frank, A.G. 1998. ReORIENT: Global Economy in the Asian Age. Berkeley and Los Angeles: University of California Press. 416 p.

[7] Fraser, N. and K. Nash, eds. 2014. Transnationalizing the Public Sphere. Cambridge: Polity Press. 168 p.

[8] Habermas, J. 1998. Between facts and norms: Contribution to a discourse theory of law and democracy. Translated from German by William Rehg. Cambridge: The MIT Press. $631 \mathrm{p}$.

[9] Habermas, J. 1984. The theory of communicative action. Volume one: reason and the rationalization of society. Translated from German by Thomas McCarthy. Boston: Beacon Press. 465 p. 
[10] Habermas, J. 1987. The theory of communicative action. Volume two: lifeworld and system. Translated from German by Thomas McCarthy. Boston: Beacon Press. 457 p.

[11] Simon, K.W. 2013. Civil society in China: the legal framework from Ancient Times to the "New Reform Era". Oxford: Oxford University Press. 502 p.

[12] Wallerstein, I., R. Collins, M. Mann, G. Derluguian and C. Calhoun. 2013. Does capitalism have a future? New York: Oxford University Press. 192 p.

[13] Wallerstein, I. 2011. The modern world-system I: capitalist agriculture and the origins of the European world-economy in the sixteenth century. Berkeley and Los Angeles: University of California Press. 410 p.

[14] Wallerstein, I. 1980. The modern world-system II: mercantilism and the consolidation of the European world-economy, 1600-1750. New York: Academic Press. 370 p.

[15] Wallerstein, I. 1989. The modern world-system III: the second era of great expansion of the capitalist world-economy, 1730-1840s. San Diego: Academic Press. 372 p.

[16] Wallerstein, I. 2011. The modern world-system IV: centrist liberalism triumphant, 1789-1914. Berkeley and Los Angeles: University of California Press. 377 p.

[17] Валлерстайн, И. 2006. Миросистемный анализ: ведение. Перевод с английского Натальи Тюкиной. Москва: Издательский дом «Территория будущего». 248 с. (Vallerstayn, I. 2006. Mirosistemnyiy analiz: vedenie. Perevod s angliyskogo N. Tyukinoy. Moskva: Izdatelskiy dom «Territoriya buduschego». 248 c.)

[18] Вебер, М. 2001. История хозяйства. Город. Перевод с немецкого И. Гревса. Москва: КАНОН-пресс-Ц, Кучково Поле. 576 с. (Veber, М. 2001. Istoriya hozyaystva. Gorod. Perevod s nemetskogo I. Grevsa. Moskva: KANON-press-Ts, Kuchkovo Pole. 576 s.)

[19] Габермас, Ю. 2000. Структурні перетворення у сбері відкритости: дослідження категорії «громадянсъке суспільство». Переклав 3 німецької А. Онишко. Львів: Літопис. 318 с. (Habermas, Yu. 2000. Strukturni peretvorennia u sferi vidkrytosty: doslidzhennia katehorii «hromadianske suspilstvo». Pereklav z nimetskoi A. Onyshko. Lviv: Litopys. 318 s.)

[20] Дарендорф, Р. 2006. У пошуках нового устрою. Лекиї̈ на тему політики свободи у XXI сторіччі. Переклав з німецької А. В. Орган. Київ: Видавничий дім «Києво-Могилянська академія». 112 с. (Darendorf, R. 2006. U poshukakh novoho ustroiu. Lektsii na temu polityky svobody $u$ XXI storichchi. Pereklav z nimetskoi A. V. Orhan. Kyiv: Vydavnychyi dim «Kyievo-Mohylianska akademiia». 112 s.) 